\title{
Model Optimalisasi Kebijakan Pembayaran Dividen
}

\author{
Sabaruddin Siagian \\ Universitas Bina Sarana Informatika \\ e-mail: sabaruddin.sdg@bsi.ac.id

\begin{tabular}{ccc}
\hline Diterima & Direvisi & Disetujui \\
$01-01-2020$ & $25-02-2020$ & $02-03-2020$ \\
\hline
\end{tabular}

\begin{abstract}
Abstrak - Kebijakan dividen yang optimal akan meningkatkan nilai perusahaan atau harga saham. Untuk membuat kebijakan dividen yang optimal dalam meningkatkan harga saham dibuatlah model optimalisasi pembayaran dividen. Tahapannya, antara lain, pertama, memastikan adanya dana untuk pembayaran dividen tersebut, Kedua, membayar dividen. Ketiga, mengambil kebijakan reinvestasi. Keempat, mengokomunikasikan kepada investor terkait kebijakan reinvestasi tersebut. Dan kelima, membuat kebijakan pendanaan untuk meningkatkan nilai perusahaan sehingga struktur permodalan perusahaan itu sehat dan efisien. untuk itu, dalam paper ini akan dibahas tuntas kebijakan model optimalisasi pembayaran dividen kepada peilik perusahaan atau peegang perusahaan sehingga masyarakat mengerti dan paham proses pembayaran dividen yang meningkatkan harga saham. Dan tahapan dari odel optimalisasi pembayaran dividen itu adalah menjadi poin utama dalam permmasalahan dan pembahasan paper ini.
\end{abstract}

Kata Kunci: Kebijakan Dividen, Harga Saham

Abstract - The optimal dividend policy will increase the company value or the stock price. To make the optimal dividend policy, thus increasing the stock price, the optimal dividend payout model is needed. First, ensure the liquidity of the dividend payout. Second, pay the dividend. Third, adopt the dividend reinventing policy. Fourth, communicate the dividend reinventing policy to the shareholders. Fifth, making the optimal funding policy. Following the model will increase the company value while ensure the safety and efficiency of the capital structure. Therefore, in this paper will be discussed and explored thoroughly the optimal dividend payout model to the owners of the company or shareholder so that society and investors will know and understand the process of the dividend payment to the owners of the company or shareholder. And, the optimal dividend payout model will be the main point of problems on the paper.

Key Words: dividend policy and stock price.

\section{PENDAHULUAN}

Sampai saat ini, peneliti akademik dan praktisi bisnis belum bisa menentukan model optimalisasi yang tepat untuk menentukan besaran nominal atau rasio pembayaran dividen kepada pemilik perusahaan atau pemegang saham perusahaan. Malahan, peneliti akademik masih memiliki perbedaan pandangan terkait kebijakan pembayaran dividen kepada pemegang saham. Penelitian akademik masih belum sepakat terkait dengan hubungan antara kebijakan pemberian dividen kepada pemegang saham terhadap kenaikan nilai perusahaan atau harga saham perusahaan.

Peneliti akademik bidang keuangan yang menjadi rujukan bagi penganut paham yang mengatakan bahwa tidak ada kaitan antara kebijakan pemberian dividen kepada pemilik perusahaan terhadap nilai perusahaan atau kenaikan harga saham adalah peneliti Merton $\mathrm{H}$. Miller dan Franco Modigliani. Kedua peneliti ini menjelaskan pandangan mereka di Journal of Business, "Dividend Policy, Growth and the Valuation of Shares". Merton dan Miller menegaskan bahwa yang meningkatkan nilai perusahaan atau nilai harga saham adalah kemampuan aktiva atau harta perusahaan menghasilkan pendapatan atau earning dan risiko yang terkandung dalam harta tersebut bukan kepada kebijakan dividen perusahaan (Gitman \& Zutter, 2015).

Di lain pihak, peneliti Myron J. Gordon dan John Lintner menghasilkan teori Bird-in-Hand Argument. Kedua peneliti keuangan ini menegaskan bahwa kebijakan pemberian dividen sangat relevan terhadap peningkatan perusahaan atau kenaikan harga saham. Gordon dan Lintner dalam teori itu mengatakan bahwa pemberian dividen saat ini sangat lebih pasti dari pada capital gains yang diterima akan datang (Gitman \& Zutter, 2015).

Dalam studi empiris dalam kasus-kasus pemberian dividen di dalam industri atau perusahaan umumnya terjadi variasi atau tidak seragam dalam rujukan dalam pemberian dividen. Rasio dan jumlah nominal pemberian dividen kepada pemilik perusahaan atau pemegang saham terhadap laba tidak ada yang seragam.

Dengan belum adanya kesepakatan itu, baik peneliti maupun praktisi bisnis terkait dengan jumlah nominal yang tepat atau rasio dari laba, maka artikel ini akan memberikan model optimalisasi kebijakan 
pemberian dividen kepada pemilik perusahaan atau pemegang saham.

Dengan begitu, penulis membuat permasalahan dalam artikel ilmiah ini adalah bagaimana model optimalisasi kebijakan pemberian dividen kepada pemilik perusahaan atau pemegang saham.

Secara umum pengertian atau definisi dari dividen adalah pembayaran kepada pemilik perusahaan atau pemegang saham atas hasil usaha perusahaan atau laba perusahan.

Untuk menjelaskan lebih dalam pengertian atau definisi dividen, di sini diberikan pendapatpendapat ahli. Dividen adalah pembagian uang tunai kepada pemegang saham atas keuntungan perusahaan baik yang diperoleh dari tahun berjalan atau pun dari laba yang diperoleh dari tahun sebelumnya ( Brigham, 2011). Dividen adalah distribusi yang dilakukan perusahaan kepada para pemegang saham secara proporsional sesuai dengan pemilikan saham perusahaan (Sartono, 2000).

Saat ini sudah beragam jenis dividen. Bukannya hanya saham tunai ( cash dividend ) dan dividen saham ( stock dividend ) saja, tetapi ada juga jenis dividen lain, deviden properti ( property dividend ), dan dividen hutang ( scrip dividend ).

Tapi dalam paper ini yang dijelaskan hanya dividen tunai dan dividen saham. Pasalnya, di dalam industri praktek yang dominan yang berlaku adalah pembayaran dividen tunai dan dividen saham. Jenis dividen lain jarang digunakan.

Dividen tunai adalah dividen yang dibayarkan dalam bentuk tunai yang pada umumnya dividen tunai lebih disukai oleh para pemegang saham (Brigham, 2011). Dan dividen saham adalah dividen yang dibayarkan dalam bentuk saham dan bukan bentuk uang tunai (Brigham, 2011 ).

Teori-teori dalam kebijakan dividen selama ini yang dikeluarkan peneliti keuangan, antara lain, ( Gitman \& Zutter , 2015 ).

Teori dividen yang tidak relevan ( dividend irrelevance theory).

1. Teori ini dimotori oleh Miller dan Modiglini. Teori ini mengatakan bahwa kebijakan pembayaran dividen tidak mempengaruhi nilai perusahaan atau harga saham. Kedua peneliti ini mengatakan juga bahwa kenaikan nilai perusahaan atau harga saham ditentukan kemampuan aset atau aktiva perusahaan menghasilkan pendapatan dan kandungan risiko yang terdapat di dalam aktiva perusahaan.

2. Teori dividen yang relevan (dividend relevance theory ).

Teori ini dicetuskan oleh Gordon dan Lintner. Kedua peneliti ini mengatakan, ada hubungan antara kebijakan pembayaran dividen terhadap nilai perusahaan atau harga saham. Menurut peneliti ini, dividen yang diterima saat ini lebih baik dan pasti dibandingkan capital gains yang mana tidak pasti,
3. Informational content theory.

Teori ini menjelaskan bahwa kenaikan dividen berarti mencerminkan prospek perusahaan dan pendapatan periode berikut akan meningkat. Sebaliknya, jika pembayaran dividen turun berarti mencerminkan prospek perusahaan atau pendapatan perusahaan menurun.

4. Clientile effect ( teori efek pelanggan )

Kita mengeahui bahwa terdapat banyak kelompok investor dengan berbagai kepentingan. Ada investor yang lebih menyukai memperoleh pendapatan saat ini seperti halnya indvidu yang sudah pensiun sehingga investor ini menghendaki perusahaan untuk membayar dividen yang lebih tinggi. Tetapi ada pula investor yang lebih menyukai untuk menginvestasikan kembali pendapatan mereka karena kelompok investor ini berada dalam tarif pajak yang cukup tinggi.

Jika perusahaan menahan laba setelah pajak maka investor yang menyukai pembayaran dividen akan kecewa. Mereka memang akan menerima akan capital gains, tetapi untuk memenuhi kebutuhan, mereka terpaksa menjual sebagian sahamnya. Sementara itu investor yang memilih untuk menginvestasikan kembali pendapatannya menghendaki perusahaan untuk membayar dividen yang rendah, karena bagi mereka pembayaran dividen yang besar berarti pajak yang dibayar juga semakin besar. Ini terjadi karena mungkin kenaikan dividen mengakibatkan kenaikan tarif pajak pendapatan sehingga pembayaran dividen tidak menguntungkan dibandingkan dengan kenaikan pajak yang harus dibayar. Dengan demikian, paling tidak terdapat dua kelompok investor dengan dua kepentingan yang bertentangan.

Dengan adanya dua kelompok investor tersebut, perusahaan dapat menentukan kebijakan dividen yang oleh manajemen yang dianggap paling baik. Kemudian membiarkan investor yang tidak menyukai kebijakan dividen perusahaan menjual saham mereka; dengan kata lain membiarkan investor melakukan pemindahan investasi dari satu perusahaan ke perusahaan lain. Tetapi perlu diingat bahwa transaksi itu berlangsung secara tidak efisien karena adanya biaya transaksi dan pembayaran capital gains sebagai akibat penjualan saham. Oleh karena itu ada kecenderungan perusahaan untuk enggan melakukan perubahan kebijakan dividen. Karena perubahan kenaikan dividen mengakibatkan beberapa investor akan menjual sahamnya dan akibatnya dapat menurunkan harga saham.

Pembicaraan kebijakan dividen sejauh ini hanya aspek teorinya saja, tetapi belum melihat pertimbangan manajerial dalam praktik yang sesungguhnya. Berikut ini faktor-faktor yang sesungguhnya terjadi dan harus dianalisis dalam kaitannya dengan kebijakan dividen (Sartono: 2000 ).

1. Kebutuhan dana perusahaan 
Kebutuhan dana bagi perusahaan dalam kenyataannya merupakan faktor yang diperhitungkan dalam menentukan kebijakan dividen yang akan diambil. Aliran kas perusahaan yang diharapkan, pengeluaraan modal di masa mendatang yang diharapkan, kebutuhan tambahan piutang dan persediaan, pola pengurangan utang dan masih banyak lagi faktor lain mempengaruhi posisi kas perusahaan harus dipertimbangkan dalam analisis kebjiakan dividen.

2. Likuiditas

Likuiditas perusahaan perusahaan merupakan pertimbangan utama dalam banyak kebijakan dividen. Karena dividen bagi perusahaan merupakan kas yang keluar, maka semakin besar posisi kas dan likuiditas perusahaan secara keseluruhan akan semakin besar kemampuan perusahaan untuk membayar dividen. Perusahaan yang sedang mengalami pertumbuhan dan profitable akan memerlukan dana yang cukup besar guna membiayai investasinya. Oleh karena itu, mungkin akan kurang likuid karena dana yang diperoleh lebih diinvestasikan pada aktiva tetap dan aktiva lancar yang permanen.

Likuiditas perusahaan yang sangat besar pengaruhnya terhadap investasi perusahaan dan kebijakan pemenuhan kebutuhan dana. Keputusan investasi akan menentukan tingkat ekspansi dan kebutuhan dana perusahaan, sementara itu keputusan pembelanjaan ( keputusan pemenuhan kebutuhan dana ) akan menentukan pemilihan sumber dana untuk membiayai investasi tersebut.

3. Kemampuan meminjam.

Posisi likuiditas perusahaan dapat diatasi dengan kemampuan perusahaan untuk meminjam dalam jangka pendek. Kemampuan meminjam dalam jangka pendek tersebut akan meningkatkan fleksibilitas likuidatas perusahaan. Selain itu fleksibilitas perusahaan juga dipengaruhi oleh kemampuan perusahaan untuk bergerak di pasar modal dengan mengeluarkan saham. Kemampuan meminjam yang lebih besar, fleksibilitas yang lebih besar akan memperbesar kemampuan membayar dividen.

Dalam menentukan dividen payout ratio banyak perusahaan membandingkannya dengan industri, khususnya dengan perusahaan yang memiliki tingkat pertumbuhan yang sama. Meskipun belum tentu sama, namun akan lebih mudah untuk melihat posisi perusahaan dalam industri. Akhirnya perusahaan juga harus menilai pengaruh informasi atas dividen, apa yang diharapkan investor? Dalam kaitan itu maka analisis surat berharga sangat membantu.

4. Keadaan pemegang saham
Jika perusahaan itu kepemilikan sahamnya relatif tertutup, manajemen biasanya mengetahui dividen yang diharapkan oleh pemegang saham dan dapat bertindak dengan tepat. Jika hampir semua pemegang saham berada dalam golongan high tax dan lebih suka memperoleh capital gains, maka perusahaan dapat mempertahankan dividen payout ratio yang rendah. Dengan dividen payout rasio yang rendah tentunya dapat diperkirakan perusahaan akan menahan laba untuk kesempatan investasi yang profitable. Untuk perusahaan yang jumlah pemegang sahamnya pemegang sahamnya besar hanya dapat menilai dividen yang diharapkan pemegang saham dalam konteks pasar.

5. Bagi para investor faktor stabilitas dividen akan lebih menarik dari pada dividen payout ratio yang tinggi. Stabilitas di sini dalam arti tetap memperhatikan tingkat pertumbuhan perusahaan, yang ditunjukkan oleh koefisien arah yang positif. Apabila faktor lain sama, saham yang memberikan dividen yang stabil; selama periode tertentu akan mempunyai harga yang lebih tinggi dari pada saham yang membayar dividennya dalam prosentase yang tetap terhadap laba.

Kebijakan dividen perusahaan harus diformulasikan dengan berdasarkan kepada dua arus utama yaitu kecukupan pendanaan dan memaksimalkan peningkatan nilai perusahaan atau menaikkan harga saham pemilik perusahaan (Van Horne \& Wachowicz, 2011).

Atas dasar pernyataan Van Horne dan Wachowicz, maka paper ini mengembangkan model atau sistim dalam kebijakan pemberian dividen kepada pemegang saham. Model atau sistim pengambil keputusannya diberikan, antara lain:

1. Tersedianya pendanaan dalam pembayaran dividen.

Walaupun sudah tersedia laba disisakan untuk pembayaran dividen kepada pemegang saham tapi bila dana berupa tunai tidak tersedia atau perusahaan itu tidak likuid maka program pemberian dividen ini tidak bisa dilaksanakan.

2. Pembayaran dividen.

Dalam telahan teoritis dan praktek bisnis umumnya perusahaan membayar dividen walaupun dividen yang dibayar sangat kecil.

3. Melakukan reinvestasi terhadap anggaran dividen.

Dalam periode tertentu, perusahaan melakukan investasi besar-besaran maka memerlukan dana yang besar. Untuk memenuhi pendanaan investasi besar itu bisa saja ambil dari anggaran dividen itu.

4. Melakukan komunikasi terhadap pemilik perusahaan atau pemegang saham atas dilakukan reinvestasi dan kebijakan korporasi 
yang strategik serta menjelaskan prospek industri yang digarap.

5. Membuat keputusan kebijakan pendanaan yang optimal.

\section{METODE PENELITIAN}

Metode penelitian yang digunakan untuk membuat artikel ilmiah ini adalah dengan mengandalkan kajian literatur dan mengobservasi perilaku industri atau perusahaan Indonesia dalam kebijakan mereka memberikan dividen kepada pemegang saham selama bertahun-tahun.

\section{HASIL DAN PEMBAHASAN}

Dalam pembahasan ini dititikberatkan pemaparan atau pembahasan dari model optimalisasi pembayaran dividen kepada pemilik perusahaan atau pemegang saham. Dalam kebijakan pembayaran dividen memang harus disiapkan anggaran membayar dividen kepada pemegang saham. Kendati ada rencana untuk memberikan dividen tunai kepada pemegang saham, tapi dana yang tersedia tidak cukup membayar dividen, maka program pemberian dividen tidak bisa berjalan. Untuk itu, perusahaan harus merencanakan dengan baik pendanaan untuk pembayaran dividen itu. Perusahaan harus memperhatikan manajemen likuiditasnya. Atau, perusahaan harus memperhatikan rasio keuangan perusahaan itu, khususnya rasio lancar yang terkait kemampuan perusahaan untuk membayar tagihantagihan perusahaan berdurasi jangka pendek. Jadi, prasyarat pertama dalam pemberian dividen adalah penyediaan dana untuk membayar dividen itu.

Paradigma baru dalam khasanah dunia keuangan atau finansial adalah terjadinya perubahan tujuan perusahaan. Tujuan perusahan dalam paradigma lama tujuan perusahaan adalah bagaimana mencapai laba atau profit yang sebesar-besarnya. Tapi paradigma baru dalam bidang keuangan adalah tujuan perusahaan adalah menjadi mencapai nilai perusahaan sebesar-besarnya atau sama dengan memaksimalkan harga saham. Tujuan perusahaan harus dicapai oleh perusahaan atau manajer keuangan adalah bukan memaksimalkan profit melainkan memaksimalkan kemakmuran pemegang saham atau maximization wealth of stockholders melalui maksimisasi nilai perusahaan.

Dari studi keuangan dan finansial lebih satu dekade mengajar ilmu keuangan, ditemukan bahwa seluruh keputusan aspek keuangan dan investasi termasuk pembuataan kebijakan pembagian dividen harus mengaju kepada pemaksimalan nilai perusahaan atau memaksimalkan harga saham.

Teori bird-in-the-hand argument oleh Gordon dan Lintner yang menyatakan bahwa dividen yang diterima oleh pemegang saham adalah menjadi lebih baik atau lebih pasti daripada capital gains yang lebih berisiko yang tinggi tidak menerima dari pendapatan atas pemilikan perusahaan.

Dalam praktek bisnis, dan pengamatan dalam dunia bisnis dan investasi, jika sebuah perusahaan menaikkan pembayaran dividennya kepada pemegang saham, maka harga saham perusahaan itu meningkat. Sebaliknya bila perusahaan itu menurunkan pembayaran dividennya maka harga saham perusahaan itu menurun.

Dalam valuasi saham yang digunakan praktisi bisnis dan akademisi dapat dibuktikan adanya kaitan antara peningkatan pemberian dividen dengan kenaikan harga saham. Salah satu formulasi yang sangat banyak digunakan dalam menghitung harga saham adalah menggunakan Gordon growth model. Dengan rumus $\mathrm{Po}=\mathrm{D} 1 /(\mathrm{Rs}-\mathrm{g})$. D1 adalah dividen, maka dengan peningkatan pembayaran dividen otomatis dihasilkan peningkatan kenaikan harga saham.

Teori keuangan lain membuktikan bahwa ada relevansi antara peningkatan pembayaran dividen terhadap peningkatan harga. Yakni, teori keuangan Informational Content, menyatakan, jika ada peningkatan pemberian dividen, pasar akan merespons adanya kenaikan harga saham. Sebaliknya jika pemberian dividen berkurang, pasar merespons juga adanya penurunan harga saham. Artinya juga, jika terjadi peningkatan dividen maka hal itu menandakan bahwa di periode-periode berikutnya akan ada peningkatan pendapatan maka pasar merespons adanya peningkatan harga saham. Sebaliknya juga, bila ada penurunan pembayaran dividen itu pertanda bahwa masa depan pendapatan perusahaan itu menurun maka harga saham menurun. Dengan demikian, perusahaan harus memberikan dividen yang cukup kepada pemilik perusahaan atau pemegang saham bila perusahaan itu ingin ada peningkatan nilai perusahaan. Makanya, perusahaan perlu mengelola kebijakan pembayaran dividennya sehingga kebijakan itu memaksimalkan nilai perusahaan.

Terkait dengan pembahasan reinvestasi anggaran pembayaran saham. Secara teoritis dan praktek bisnis dapat juga perusahaan itu menurunkan drastis pembayaran dividen atau tidak memberikan dividen kepada pemegang saham. Secara umum akan terjadi penurunan harga saham. Tidak diberikannya dividen itu bisa karena performa perusahaan menurun atau terjadinya masalah likuiditas di perusahaan itu atau masalah-masalah lain. Hal ini wajar karena pendapatan investor atau pemegang saham menurun. Karena penurunan pendapatan itu maka pemegang saham merespons menjual sahamnya atau mengurangi portofolio saham tersebut sehingga akhirnya harga saham menurun.

Akan tetapi, pada kasus ini ada rencana reinvestasi atas anggaran dividen yang sebenarnya disiapkan untuk pembayaran dividen kepada pemegang saham. Kalau reinvestasi terjadi dan performa perusahaan baik, apa yang terjadi terhadap performa harga saham perusahaan itu? Dengan reinvestasi dividen ini dimaksudkan penggunaan dividen itu untuk pengembangan bisnis atau rencana ekspansi perusahaan yang besar-besaran. Reinventasi dividen bisa saja tujuannya mengganti pendanaan 
dari pihak ketiga karena mahalnya biaya suku bunga atau biaya modal dari pinjaman dari lembaga keuangan atau juga tetap membuat moderat biaya modal perusahaan atau membuat leverage atau struktur modal dan hutang yang sehat.

Walaupun reinvestasi ini rencana bisnis yang baik untuk memperbesar skala perusahaan yang lebih besar tapi bila perusahaan tidak membayar dividen tetap saja terjadi penurunan harga saham perusahaan. Pasalnya, investor atau pemegang saham perusahaan itu akan menjual saham perusahaan itu dikarenakan pendapatan dari dividen itu hilang. Hilangnya pendapatan itu karena tidak menerima dividen membuat pembiayaan hidup investor itu akan terganggu. Investor atau pemegang saham akan mencari saham yang memberikan dividen untuk membiaya hidup investor itu. Dengan menjual saham tersebut otomatis harga saham perusahaan itu menurun. Biasanya investor seperti adalah individuindividu yang menggantungkan hidup mereka dari penghasilan penerimaan dari dividen dan perusahaan yang mengelola dana pensiun.

Untuk mencegah penurunan harga saham ini perlu komunikasi yang intens kepada investor atau pemegang terkait dengan aksi korporasi yang dilakukan oleh perusahaan itu dengan menjelaskan utuh rencana yang baik reinvestasi itu. Komunikasi itu harus menghasilkan penjelasan kebaikan reinvestasi itu dan manfaat yang sangat besar di kemudian hari kepada investor dan pemegang saham. Detailnya perusahaan harus mengomunikasikan capital gains yang lebih besar diperoleh investor di kemudian hari dengan adanya rencana reinvestasi itu. Jika komunikasi yang dilakukan oleh perusahaan itu berhasil, penurunan harga saham tidak signifikan terjadi karena investor tahu rencana bisnis perusahaan itu dengan baik dan capital gains akan diperoleh lebih besar di kemudian hari atas keberhasilan proyek perusahaan itu dalam menghasilkan pendapatan atau earning. Otomatis investor -investor yang berpreferensi jangka panjang tidak menjual sahamnya malahan menambah portfolio saham itu. Kendati harus diakui investor individu yang bertumpu pembiayaan hidupnya dari penghasilan dividen atau perusahaan dana pensiun akan menjual saham tersebut.

Keberhasilan komunikasi ini supaya tidak menurunkan harga saham perusahaan itu tergantung kepada kemapanan atau efesensi pasar keuangan atau pasar modal di negara tersebut dan juga efisiensi informasi di pasar modalnya. Bila industri pasar modal sudah mapan dan efisiensi informasi sangat memadai maka bias informasi antara manajemen perusahaan dengan investor atau pemegang saham sangat sempit maka aksi korporasi perusahaan dengan melakukan reinvestasi itu sangat dimengerti investor sehingga penurunan harga saham dapat dicegah. Pasar modal yang mapan itu di negaranegara maju. Sebaliknya di negara berkembang seperti Indonesia yang pasar modal belum efisien biasanya informasi antara perusahaan dengan investor agak jauh biasnya sehingga aksi korporasi seperti reinvestasi sebagian besar tidak dimengerti oleh para investor. Biasanya di negara-negara berkembang bila terjadi tidak memberikan dividen karena reinvestasi maka harga saham perusahaan tersebut akan menurun. Jadi, fungsi keterbukaan informasi dan komunikasi yang intens sangat penting di pasar modal di negara maju. Sebaliknya di negara berkembang efektivitas komunikasi dalam mencegah penurunan harga saham akibat reinvestasi sangat terbatas.

Terkait dengan kebijakan pendanaan yang optimal. Dengan manajemen pemberian dividen yang tepat tentu berkorelasi positif dengan kenaikan harga saham. Dengan kenaikan harga saham tersebut, maka bila perusahaan mengadakan penarikan dana melalui penjualan saham kembali atau right issue melalui pasar modal maka bisa memperoleh dana yang besar dan kekuatan modal perusahaan akan kuat. Dengan kuatnya modal perusahaan tersebut maka perusahaan dalam pembiayaan proyek atau pengembangan usahanya bisa mengimbangi menggunakan dana pinjaman dari pihak ketiga atau lembaga keuangan atau perbankan. Sehingga leverage pendanaan perusahaan atau tingkat berhutangnya itu sangat aman dan biaya murah. Pada akhirnya struktur permodalan - perbandingan antara modal dengan utang menjadi sehat dan optimal dan biaya modal perusahaan rendah. Dengan begitu perusahaan memiliki daya saing pendanaannya besar di bandingkan pesaingnya di industry.

\section{KESIMPULAN}

Sangat pentingnya membuat manajemen kebijakan pemberian dividen terhadap pemilik perusahaan atau pemegang saham. Jika perusahaan mampu meningkatkan pembayaran dividen kepada pemilik perusahaan maka akan meningkatkan harga saham. Sebaiknya bila tidak mampu memberikan dividen otomatis juga menurunkan harga saham perusahaan. Untuk itu perlu membuat model optimalisasi pembayaran dividen kepada pemegang saham.

Model optimalisasi pemberian dividen kepada pemegang saham ini masih jauh dari sempurna maka diperlukan studi lagi untuk mendapatkan model yang lebih baik dan tepat. Dan sekaligus paper ini menjadi sumber inspirasi bagi masyarakat yang berkecimpung di dunia pembuatan software atau program untuk membuat program model optimalisasi pemberian dividen.

\section{REFERENSI}

Baridwan, Z. (2013). Intermeadiate Accounting. Yogyakarta: BPPE Yogyakarta.

Brigham, E., F. ( 2010 ). Dasar-Dasar Manajemen Keuangan. Jakarta: Salemba Empat. 
Gitman, L., J. \& Zutter, C., J. (2015 ). Principles of Managerial Finance. USA: Prentice Hall.

Keown, et al. (2000). Manajemen Keuangan. Jakarta: Penerbit Salemba.

Sartono, A. (2010). Manajemen Keuangan Teori dan Aplikasi. Yogyakarta: BPFE.

Van Horne J., C. (2010). Prinsip-prinsip Manajemen Keuangan. Jakarta: Salemba Empat

PROFIL PENULIS

Sabaruddin Siagian, S.E., M.M., dosen Universitas
Bina Informatika (UBSI) Jakarta sudah selama sembilan tahun mengajar. Penulis mengampuh mata kuliah manajemen, akuntansi, keuangan dan metode penelitian di UBSI. Sebelum menjadi dosen UBSI Jakarta, bekerja Kantor Pusat P.T. Panin Bank Tbk di jalan Sudirman Jakarta. Selama menjadi pegawai P.T. Bank Panin Tbk memiliki juga profesi sebagai analisis dan penulis masalah perbankan dan ekonomi. Penulis mendapatkan srata 1 (S1) dari Fakultas Ekonomi Universitas Mpu Tantular Jakarta. Dan strata 2 (S2) dari Program Magister (MM) dari Universitas Pancasila Jakarta. 